\title{
Mathematical Resilience MaHaSisWa PADA Mata KuliaH StrukTUR AlJABar I MENggunakan PENDEKatan EXPlisit INSTRUCTION INTEGRASI PEER INSTRUCTION
}

\section{MATHEMATICAl RESILIENCE STUDENTS In AlgEBRA STRUCTURE I CoURSE USING EXPLICIT INSTRUCTION APPROACH PEER INSTRUCTION INTEGRATION}

\author{
Elsa Komala \\ Program Studi Pendidikan Matematika, Universitas Suryakancana \\ Cianjur, Jawa Barat, Indonesia \\ elsakomala@gmail.com
}

\begin{abstract}
Abstrak
Tujuan artikel ini adalah untuk mendeskripsikan resiliensi matematik mahaisiwa dengan pendekatan explisit instruction integrasi peer instruction pada matakuliah Struktur Aljabar I. Untuk mendapatkan data hasil penelitian digunakan instrumen berupa tes soal Ujian Akhir Semester untuk mengetahui kemampuan matematis mahasiswa dan angket resiliensi matematik. Hasil penelitian menunjukkan bahwa pembelajarannya menggunakan pendekatan explisit instruction integrasi peer instruction memiliki resiliansi matematik sebagian besar positif, artinya mahasiswa memiliki sikap menyesuaikan diri terhadap pembelajaran matematika, yang memungkinkan mereka untuk terus belajar meskipun hambatan dan kesulitan terjadi, tekun, yakin dan tidak menyerah dengan kegagalan, mau mencoba ide-ide baru untuk menyelesaikan masalah matematis, mau bersosialisasi dan berdiskusi dengan lingkungan atau teman untuk mencari solusi lain dan menggunakan pengalaman kegagalannya untuk membangun motivasi dalam memunculkan ide dan menyelesaikan masalah matematis.

Kata Kunci: Resiliensi Matematik, Pendekatan Explisit Instruction, Peer Instruction.
\end{abstract}

\begin{abstract}
The purpose of this article is to describe the resilience of mathematics mahaisiwa with explicit explanation instruction of peer instruction integration in Algebra Structure I course. To get the result of research data used instrument in the form of test about final exam of Semester to know mathematical ability of student and mathematical resilience questionnaire. The result of the research indicates that the learning using explicit instruction approach of peer instruction integration has mostly positive mathematical resonance, meaning that students have the attitude of adjusting to mathematics learning, which enables them to keep learning even though obstacles and difficulties occur, assiduous, confident and do not give up with failure, want to try new ideas to solve mathematical problems, want to socialize and discuss with the environment or friends to find other solutions and use the experience of his failure to build motivation in generating ideas and solve mathematical problems.
\end{abstract}

Keyword: Mathematical Resilience, Explicit Instruction Approach, Peer Instruction.

\section{Pendahuluan}

Matematika merupakan ilmu yang abstrak, maka memahaminya memerlukan daya abstraksi serta kemampuan yang memadai. Ini akan menjadi masalah ketika mahasiswa yang akan mempelajarinya belum terbiasa dan belum mampu berfikir abstrak. 
Sayangnya, pengalaman yang sering diperoleh mahasiswa dalam belajar matematika sebelumnya atau pada jenjang sebelumnya misalnya SD, SMP, dan SMA fokus pada perolehan keterampilan menemukan solusi latihan rutin, dibiasakan pada persiapan tes dan ujian kecepatan dalam menghitung matematika. Sesuai dengan tipe berfikir dalam matematika, pada jenjang perguruan tinggi, dalam hal ini mahasiswa pendidikan matematika seharusnya sudah pada tahap berpikir abstrak, artinya mahasiswa sudah bisa memahami materi walau tanpa perantara (alat peraga). Sejalan dengan Tall (2002), perubahan dari berpikir elementer ke berpikir matematis tingkat lanjut melibatkan suatu transisi yang signifikan, yaitu dari mendeskripsikan ke mendefinisikan, dari meyakinkan ke membuktikan secara logika berdasarkan pada suatu definisi. Proses peralihan tersebut merupakan suatu masalah bagi mahasiswa.

Materi matematika, pada tahap berpikir abstrak sudah tidak memandang materi matematika tersebut sesuatu yang harus dikonstruksi dari masalah kontekstual. Sehingga, matematika bukanlah suatu ilmu yang mudah untuk dikuasai. Menurut pendapat Artigue (1998) dan Cornu (1991) bahwa pembelajaran matematika sering dinilai negatif oleh mahasiswa dan mereka memiliki kesulitan yang cukup besar terhadap beberapa proses matematika seperti penalaran, pemecahan masalah yang tidak rutin, dan membuktikan. Hal itu meningkatkan rasa cemas dan menghindar dari kegiatan yang memerlukan abstraksi matematik. Rasa cemas dalam belajar metematika sejalan dengan beberapa penelitian (Ashcraft, 2002; Rodarte-Luna dan Sherry, 2008; dalam Johnston-Wilder, lee 2010a) juga menunjukan bahwa siswa belajar matematika dengan rasa takut. Oleh karena itu seorang pengajar harus bisa memilih dan melaksanakan pendekatan pembelajaran matematika tertentu selain mereka berusaha membantu pelajar untuk mengatasi kesulitan untuk mencapai kemampuan matematik, dan mereka juga berusaha mengembangkan sikap positif terhadap matematika dan pembelajaran matematika. Sikap positif tersebut termuat dalam rasa tekun dan tangguh menghadapi tantangan atau kesulitan dalam belajar matematika, yang disebut resiliensi matematik (Mathematical Resilience) menurur Johnston-Wilder, Lee (2010a).

Resiliensi matematik diperlukan, pada saat mahasiswa menggunakan matematika, dan berpikir serta bersikap secara matematik dan bukan sekedar memperoleh nilai atau lulus pada matakuliah saja. Mahasiswa yang memiliki resiliensi yang kuat selain dia akan memiliki kemampuan matematik yang diperlukan untuk menjawab semua soal-soal yang diberikan pada saat ujian, juga memiliki keterampilan matematika yang diperlukan di luar perkuliahan dan 
berkeinginan menerapkannya dalan kehidipan kapan saja ketika diperlukan.

Dalam perkuliahan struktur aljabar I yang dilaksanakan, perlu adanya pengembangan resiliensi matematik. Dalam hal ini mahasiswa harus yang memiliki resilensi yang baik, artinya sadar bahwa mereka harus berpikir keras untuk menghadapi materi yang abstrak, berdiskusi dengan temannya, membaca ide-ide matematika dan merefleksi pengetahuan yang diperolehnya, dan juga mereka harus tangguh dan dapat mengatasi hambatan-hambatan dalam perkuliahan struktur aljabar I serta mampu menyelesaikan masalah yang sulit. Nurlaelah dan Sumarmo (2009) mengungungkapkan bahwa mata kuliah struktur aljabar merupakan suatu mata kuliah yang memuat konsep-konsep yang abstrak, karena sifat dari mata kuliah tersebut seperti itu maka mahasiswa seringkali mendapat kesulitan dalam mempelajarinya.

Matematika yang sifatnya abstrak dianggap sulit utuk dikuasai, dan resiliensi matematik masih kurang, sebagian besar mahasiswa dalam mengontrol diri dan menghadapi masalah dalam pembelajaran matematika masih tergolong lemah. Berdasarkan perkuliahan pada semester sebelumnya mahasiswa dalam menghadapi kesulitan dan hambatan dalam belajar atau menyelesaikan soalsoal yang diberikan, mereka tidak terdorong untuk bertanya pada sumber lain atau teman sebayanya yang lebih faham atau bahkan kepada dosen sekalipun, baik itu di dalam perkuliahan ataupun diluar perkuliahan melainkan menghindari tugas yeng menurut mereka sulit dan abstrak. Sehingga, mahasiswa tersebut lebih memilih untuk menyalin pekerjaan temannya saja tanpa memahaminya terlebih dahulu. oleh karena itu mahasiswa harus mampu mengembangkan resiliensi matematik. Untuk mengembangkan resiliensi matematik pembelajaran yang digunakan adalah pendekatan explisit instruction integrasi peer instruction pada perkuliahan struktur aljabar I, karena dalam pembelajaran ini mahsiswa bisa lebih aktif karena pembelajaran yang bertahap dan informasi yang diberikan dosen bisa langsung sampai pada mahasiswa secara deklaratif dan prosedural, mahasiswa bisa langsung aktif bertanya sesuai prosedur yang belum dipahaminya atau betanya dan berdiskusi secra peer. Hal ini sesuai dengan karakteristik dari resiliensi matematik yakni ketekunan ketika dihadapkan dengan kesulitan matematika, bekerja bersama-sama dengan rekan-rekan, memiliki kemampuan bahasa yang diperlukan untuk mengekspresikan pemahaman matematik dan memiliki teori pertumbuhan pembelajaran matematika.

Berdasarkan uraian diatas, tujuan dari artikel ini adalah untuk mengetahui resiliensi matematik yang dimiliki 
mahasiswa pada mata kuliah Struktur Aljabar I dengan menggunakan pendekatan explisit instruction integrasi peer instruction.

Pendekatan explicit intruction berkaitan dengan pengetahuan deklaratif dan pengetahuan prosedural yang terstruktur dan dapat diajarkan dengan pola kegiatan yang bertahap, selangkah demi selangkah. Strategi ini sering dikenal dengan model pengajaran langsung. Sedangkan menurut Rosenshine \& Stevens (1984) mengemukakan bahwa explicit intruction merupakan pembelajaran langsung yang khusus dirancang untuk mengembangkan belajar siswa tentang pengetahuan prosedur dan pengetahuan deklaratif yang dapat diajarkan dengan pola selangkah demi selangkah. Tahapan tersebut terdiri dari orientasi, presentasi, latihan tersetruktur, latihan terbimbing, latihan mandiri dan guru merencanakan kesempatan untuk melakukan instruksi lebih lanjut dengan berfokus pada situasi yang lebih kompleks, atau bahkan kehidupan sehari-hari.

Explicit intruction menurut Kardi (2000) dapat berbetuk ceramah, demonstrasi, pelatihan atau praktek, dan kerja kelompok. Akan tetapi tingkat struktur dan kendali guru yang tinggi dalam kegiatan pembelajaran, yang menjadi karakteristik strategi explicit intruction jangan terlalu mendominasi.

Peer instruction merupakan pembelajaran diselingi dengan pertanyaan konsep (Crouch \& Mazur,
2001) serta melibatkan keaktifan mahasiswa dalam pembelajaran (Fagen, dkk., 2002). Mahasiswa diberi kesempatan untuk berpikir dalam menyelesaikan pertanyaan konsep yang diberikan, kemudian mendiskusikan dengan teman sejawatnya. Pertanyaan konseptual singkat tersebut di dirancang untuk mengungkapkan kesalahpahaman dan untuk melibatkan mahasiswa agar aktif dalam pembelajaran. Menurut Nicol, dkk (2003) peer instruction lebih efektif daripada dengan pembelajaran diskusi kelas.

Menurut Dweck (Johnston-Wilder dan Lee, 2010a) resiliensi matematik merupakan sikap tekun atau gigih dalam menghadapi kesulitan, bekrja atau belajar kolaboratif dengan teman sebaya, memiliki keterampilan berbahasa untuk menyatakan pemahaman matematik, dan menguasai teori belajar matematik. Sedangkan menurut Newman (Johnston-Wilder dan Lee, 2010a) resiliensi matematik diartikan sebagai sikap bermutu dalam belajar matematika yang meliputi percaya diki akan keberhasilannya melalui usaha keras; menunjukkan tekun dalam menghadapi kesulitan; berkeinginan berdiskusi; merefleksi dan meneliti. Sehingga dengan resiliansi matematik memungkinkan mahasiswa bisa mengatasi hambatan dan kesulitan dalam belajar matematik, dan beradaptasi dengan lingkungan yang kurang baik dan tidak nyaman, bahkan pada lingkungan yang kurang disenangi. 
Sejalan dengan Adolphs, R dan Damasio (Garton, E. et all, 2013) mereka memiliki sikap menyesuaikan diri dengan lingkungan; dapat menghadapi ketidakpastian, masalah dan tantangan; menyelesaikan masalah secar logis dan fleksibel; mencari solusi kreatif terhadap tantangan; bersifat ingin tahu dan belajar dari pengalaman; memiliki kemmapuan mengontrol diri; sadar akan perasaanny; memiliki jaringan sosial yang kuat dan mudah memberi bantuan. Indikator resiliensi matematik yang digunkan adalah: 1) sikap tekun, yakin, dan tidak mudah menyerah menghadapi masalah dan kegagalan; 2) berkeinginan bersosialisasi dan berdiskusi dengan teman dan lingkungan; 3) menggunakan pengalaman keggalan untuk membangun motivasi diri; 4) menunjukkan kemauan untuk berusaha mencari sumber belajar sendiri melalui Ict, internet, maupun buku-buku sebelum bertanya pada teman atau dosen; 5) berani mencoba ide-ide baru umtuk menyelesaikan masalah matematis.

\section{Metode}

Penelitian ini merupakan penelitian dengan metode deskriptif dengan pendekatan kuantitatif artinya penelitian yang dimaksudkan untuk mengumpulkan informasi mengenai status suatu gejala yang ada, yaitu keadaan gejala menurut apa adanya pada saat penelitian dilakukan. Adapun subjek penelitian pada penelitian ini ini adalah mahasiswa jurusan pendidikan matematika semester 3 tingkat II kelas A yang terdri dari 32 mahasiswa Universitas Suryakancana pada mata kuliah Struktur Aljabar I.

Instrumen yang digunkan dalam penelitian ini berupa tes dan non tes. Tes diberikan pada saat Ujian Akhir Semester untuk mengetahui sejauh mana kemampuan mahasiswa dalam kemampuan kognitifnya. Instrumen nontes berupa angket resiliensi matematikskala Likert dengan empat pilihan jawaban, yaitu: Sangat Setuju (SS), Setuju (S), Tidak Setuju (TS), Sangat Tidak Setuju (STS) dengan skor 4, 3, 2, dan 1 untuk pernyataan positif, untuk pernyataan negatif skor merupakan kebalikannya. Empat pilihan ini berguna untuk menghindari pendapat siswa pada suatu pernyataan yang diajukan sehingga pada skala pendapat siswa tidak digunakan opsi Netral (N). Angket resiliensi matematik dibuat dalam bentuk pernyataan sebanyak 30 pernyataan untuk mengetahui sejauh mana resiliensi mahasiswa pada matakuliah struktur aljabar I setelah pembelajaran menggunakan pendekatan explisit instruction integrasi peer instruction.

\section{Hasil dan Pembahasan}

Tes yang diberikan pada subjek penelitian adalah tes Ujian Akhir Semester. Adapun bentuk tes yang diberikan adalah tes bentuk uraian yang berjumlah 5 butir soal. Selanjutnya hasil 
tes UAS dianalisis kemudian

dikelompokkan yaitu kelompok

kemampuan tinggi, kelompok

kemampuan sedang dan kelompok

kemampuan rendah Untuk kemampuan

tinggi skor 70-100, kemampuan sedang memiliki skor 50-69 dan kemampuan rendah skor 0-49. Tahap selanjutnya adalah pemberian angket pada semua mahasiswa yang telah melaksankan UAS untuk mengetahui resiliensi matematik.

Tabel 1.

Data Deskriptif Skor UAS Struktur Aljabar I

\begin{tabular}{|ccc|}
\hline $\begin{array}{c}\text { Kemampuan } \\
\text { Mahasiswa }\end{array}$ & $\begin{array}{c}\text { Jumlah } \\
\text { Mahasiswa }\end{array}$ & Persentase \\
\hline Tinggi & 10 & $31,25 \%$ \\
\hline Sedang & 12 & $37,5 \%$ \\
\hline Rendah & 10 & $31,25 \%$ \\
\hline Jumlah & 32 & $100 \%$ \\
\hline
\end{tabular}

Berdasarkan Tabel 1. subjek dengan skor UAS tinggi dan rendah masingmasing mencapai 10 orang atau sekitar $31,25 \%$ dari subjek yang diteliti. Subjek dengan skor UAS sedang mencapai 12 orang atau sekitar 37,5\% dari subjek yang

Tabel 2.

Persentase Resiliensi Matematik Mahasiswa

\begin{tabular}{|c|c|c|c|c|c|c|}
\hline \multirow{3}{*}{ Indikator Resiliensi Matematik } & \multicolumn{6}{|c|}{ Kemampuan Mahasiswa } \\
\hline & \multicolumn{2}{|c|}{ Tinggi } & \multicolumn{2}{|c|}{ Sedang } & \multicolumn{2}{|c|}{ Rendah } \\
\hline & Positif & Negatif & Positif & Negatif & Positif & Negatif \\
\hline $\begin{array}{l}\text { Sikap tekun, yakin, dan tidak mudah } \\
\text { menyerah menghadapi masalah dan } \\
\text { kegagalan }\end{array}$ & $90 \%$ & $10 \%$ & $58 \%$ & $42 \%$ & $50 \%$ & $50 \%$ \\
\hline $\begin{array}{l}\text { Berkeinginan bersosialisasi dan berdiskusi } \\
\text { dengan teman dan lingkungan }\end{array}$ & $60 \%$ & $40 \%$ & $83 \%$ & $17 \%$ & $90 \%$ & $10 \%$ \\
\hline $\begin{array}{l}\text { Menggunakan pengalaman kegagalan untuk } \\
\text { membangun motivasi diri }\end{array}$ & $50 \%$ & $50 \%$ & $67 \%$ & $33 \%$ & $40 \%$ & $60 \%$ \\
\hline $\begin{array}{l}\text { Menunjukkan kemauan untuk berusaha } \\
\text { mencari sumber belajar sendiri melalui ICT, } \\
\text { internet, maupun buku-buku sebelum } \\
\text { bertanya pada teman atau dosen }\end{array}$ & $90 \%$ & $10 \%$ & $83 \%$ & $17 \%$ & $80 \%$ & $20 \%$ \\
\hline $\begin{array}{l}\text { Berani mencoba ide-ide baru umtuk } \\
\text { menyelesaikan masalah matematis. }\end{array}$ & $80 \%$ & $20 \%$ & $50 \%$ & $50 \%$ & $40 \%$ & $60 \%$ \\
\hline Rata-Rata & $74 \%$ & $26 \%$ & $68,2 \%$ & $31,8 \%$ & $60 \%$ & $40 \%$ \\
\hline
\end{tabular}

Berdasarkan Tabel 2. diperoleh data bahawa hasil angket mahasiswa yang memilki kemampuan matematik tinggi, resiliensi matematik sebagian besar positif yakni sekitar 74\%, sedangkan mahasiswa yang memilki kemampuan matematik sedang, sebagian besar resiliensi matematik juga positif sekitar $68,2 \%$, dan mahasiswa yang memilki kemampuan matematik rendah, resiliensi matematik sebagian besar positif yakni sekitar $74 \%$. Jadi, rata-rata persentase keseluruan resiliensi matematik adalah $67,4 \%$ hal ini menunjukkan bahwa sebagian besar positif terhadap pembelajaran menggunakan pendekatan explicit instruction integrasi peer instruction. Hal ini diakibatkan oleh adanya demonstrasi 
guru, arahan-arahan dari guru, dan berdiskusi dengan teman sebaya (peer) sebagai petunjuk berupa pertanyan sehingga komunikasi multi arah terjadi, serta sosialiasai setiap mahasiswa muncul. Sehingga mahasiswa sedikit demi sedikit bisa mengurangi dan memecahkan hambatan yang dihadapinya dalam menyelesaikan soal atau permasalahan terutama bagi mahasiswa yang memiliki kemampuan matematik yang rendah.

Sikap tekun, yakin dan tidak mudah menyerah dalam menghadapi masalah yang diberikan dan kemungkinan kegagalan yang terjadi sangat ditunjukan baik pada mahasiswa yang memiliki kemmapuan matematik tinggi, hal ini bisa terjadi karena kebebasan berpikir dan akibat adanya diskusi kelompok dengan teman sebaya dan diskusi kelas bersama dosen yang menyebabkan hal ini berkembang. Semua mahasiswa sudah baik dalam menunjukkan kemauan untuk berusaha mencari sumber belajar sendiri melalui ICT, internet, maupun buku-buku sebelum bertanya pada teman atau dosen. Terakhir pada mahasiswa yang memiliki kemampuan tinggi baik dalam hal berani mencoba ide-ide baru umtuk menyelesaikan masalah matematis, karena mereka bisa mengeksplor kemmapuan yang mereka miliki sebelumnya dan kemamapuan baru hasil kolaborasi denagn teman kelompoknya, serta pertukaran ide terjadi dalam pembelajaran.

\section{Penutup}

Simpulan pada artikel ini adalah mahasiswa pada matakuliah struktur aljabar I yang pembelajarannya menggunakan pendekatan explisit instruction integrasi peer instruction memiliki resiliansi matematik sebagian besar positif, artinya mahasiswa memiliki sikap menyesuaikan diri terhadap pembelajaran matematika, yang memungkinkan mereka untuk terus belajar semkipun hambatan dan kesulitan terjadi, tekun, yakin dan tidak menyerah dengan kegagalan, mau mencoba ide-ide baru untuk menyelesaikan masalah matematis, mau bersosialisasi dan berdiskusi dengan lingkungan atau teman untuk mencari solusi lain dan menggunakan pengalaman kegagalannya untuk membangun motivasi dalam memunculkan ide dan menyelesaikan masalah matematis.

\section{Daftar Pustaka}

Artigue, M. 1998. Teacher Training as a Key Issue for the Integration of Computer Technologies. In T ins le y \& Jo hso $n$ ( $E$ ds), Information and Communications Technologies in School Mathematics (pp). IFIP: Chapman \& Hall.

Cornu, B. 1991. Advanced Mathematical Thinking Limits. In D. O. Tall (ed.), (pp). The Netherland: Kluwer Academic Publisher.

Crouch, C. H. \& Mazur, E. 2001. Peer Instruction: Ten years of experience and results. Department of Physics, 
Harvard University, Cambridge. Tall, D. 2002. Advanced Mathematical American Journal of Physics, 69(9): 970-977.

Thinking. USA: Kluwer Academic Publishers.

Fagen, A. P., Crouch, C. H., dan Mazur, E. 2002. Peer Instruction: Results from a Range of Classrooms., Harvard University, Cambridge.

Nicol, David J, James T. Boyle. 2003. Peer Instruction versus Class-wide Discussion in Large Classes: a comparison of two interaction methods in the wired classroom. Centre for Academic Practice, University of Strathclyde. Studies in Higher Education, 28 (4): 457-473.

Nurlaelah, E dan Sumarmo, U. 2009. Sumarno U., 2009. Implementasi Model Pembelajaran Apos dan Modifikasi- APOS (M-APOS) pada Matakuliah Struktur'Aljabar. FMIPA Garton, E. et all. (2013). Coaching for Mathematical Resilience: Foundation Level Internal Evaluation. Coventry: The Progression Trust, University of Warwick and Asdon.

Johnston, Wilder and lee, C. (2010). Children Overheard: Working to increase Mthematical Resilience. Mti, ATM, Summer.

Kardi, Soeparman dan Muhamad Nur. 2000. Pengajaran Langsung. Surabaya: Universitas Negeri Surabaya Universiti Press.

Rosenshine, Barak, and Robert Stevens. 1984. "Classroom instruction in reading." Handbook of reading research 1. Hal: 745-798. UPI. 